"økologien" - lider slemt under den grænseløse vækst, som kendetegner kapitalismens globale ekspansion og udbredelse. Her har Becks sociologi helt sikkert sin berettigelse som analyse- og kritikform.

Også den kritiske analyse, som Beck leverer af fuldbeskæftigelsessamfundets endeligt virker særdeles overbevisende og aktuel. Selv i en p.t. velkørende og sund økonomi som den danske vil arbejdsløsheden aldrig blive udryddet og fremtidens arbejdsmarked vil i høj grad basere sig på flere og flere deltids- og freelanceansættelser med den fundamentale usikkerhed som sådanne ansættelser indebærer. Becks svar på denne udfordring er, at vi må til at nytænke arbejdsmarkedet - bl.a. med indførsel af en kættersk tanke og praksis som betalt borgerarbejde (dvs. en slags borgerløn) som et supplement til det traditionelle erhvervsarbejde. En praksis, der - udover måske at øge samarbejdet, den demokratiske sans og sammenhængskraften i samfundet "ved at bringe folk sammen for at løse samfundsmæssige opgaver og problemer" (s. 133) i fællesskab - også ville kunne løse nogle af de mange udfordringer, som de europæiske velfærdsstater p.t. står overfor. En sympatisk tankegang, der dog, kan man frygte, savner resonansbund i den nuværende samfundsmæssige "virkelighed".

Paw Hedegaard Amdisen

\section{Islam i fremtidens Danmark}

Sherin Khankan: Islam \& forsoning - en offentlig sag, Lindhardt og Ringhof, 2006, 275 sider, $249 \mathrm{kr}$.

Sherin Khankans bog Islam \& forsoning er et meget personligt og insisterende indlæg $\mathrm{i}$ debatten om islams rolle i Europa. Sherin Khankan spiller i sit indledende kapitel klart og tydeligt ud: "Jeg mener ikke at der er en naturgiven modsætning mellem islamiske principper og det danske demokrati" (s.14). Dette udsagn gentages i mange versioner, det er en tilbagevendende konklusion på alle de forhold Khankan gennemgår i bogen.

Khankan forudsætter, at der er en vis konsensus om, hvad der er Vesten og vestlige værdier som eksempelvis sekularisering og demokrati. Hun vil så introducere læseren til en islamisk aktivisme, som er forenelig med dette Vesten. Det kan være lidt svært at overskue, hvordan hun har bygget bogen og dermed argumentationen for sit synspunkt op. Men en måde at få vendt de væsentligste sten på er ved at anskue argumentationen som opbygget af koncentriske cirkler: familie, islam, og samfundsengagementet herunder kvindesagen.

Sherin Khankan er "halfie" - halvt finne og halvt syrer. Hendes kristne mor voksede op på landet i en familie med otte børn, hun blev uddannet til sygeplejerske og rejste til Danmark. Khankans muslimske far er søn af en butiksejer i Damaskus, og han er den 
eneste af en søskendeflok på seks, der fik en videregående uddannelse. Khankans`s far og mor mødte hinanden i København, giftede sig og fik to døtre. Khankan er altså i bogstaveligste forstand et barn af forsoning og respekt, hun er vokset op i et hjem, hvor to vidt forskellige kulturer har måttet finde et fælles livsgrundlag ved at fokusere på, hvad der forener og ikke hvad der adskiller.

Det er blevet Khankans dybe overbevisning, at mangfoldigheden i verden er et gode, og at mennesker kan leve sammen i et globalt fællesskab, hvor der er plads til både religiøsitet og rationalitet. Disse begreber er ikke hinandens modsætning, og islam og Vesten er ikke uforenelige størrelser.

Det er vigtigt at bemærke, at aktivisme er subjekt og islamisk er adjektiv i dette udtryk. Khankan skelner mellem religion og religiøsitet. Religionen islam med koranen som Guds åbenbarede ord er evig og uforanderlig, men religiøsiteten - dvs. den måde, man tænker og praktiserer sin religion på - er en foranderlig og dynamisk aktivitet, der forandrer sig efter de samfundsmæssige og kulturelle forhold.

Koranen er den evige tekst, men dens mening er blevet udlagt forskelligt til forskellige tider og i forskellige samfund. Koranfortolkning tafsir er en videnskab, der udøves af korankyndige ulama, men disse fortolkere skal også være fortrolige med det samfund, de lever i; de skal udlægge koranen, så det at være en aktiv mus- lim kan forenes med at være en aktiv samfundsborger. Tafsir kan sikre, at islam ikke låses fast $\mathrm{i}$ en konservativ dogmatisk udlægning af koranen, som alle muslimer over hele verden skal indordne sig under. Det er ikke koranen, der skal forandres eller forkastes, for at muslimer kan leve et aktivt og integreret liv i vestlige samfund. Ved siden af tafsir står begrebet idjtihad, som dækker det arbejde, muslimske retslærde må lægge i at udlede eller fortolke steder $\mathrm{i}$ koranen og sunna, som er svært forståelige. Der kan også være tale om, at der slet ikke foreligger tekststeder, som kan appliceres på opståede forhold, her er idjithad så det at formulere retningslinier, som er $\mathrm{i}$ harmoni med både islam og med det omgivende samfund.

Khankan refererer mange gange til filosoffen og forfatteren Tariq Ramadan og til den religiøsitet, han beskriver i bogen At vare europaisk muslim. Ramadan formulerer her fire hovedprincipper for det, som nu benævnes euroislam. Disse principper skal styrke og bekræfte muslimer $i$, at en identitetskonflikt ikke er et grundvilkår for muslimer i Europa. Principperne omhandler både rettigheder og pligter. Muslimer har ret til at få deres tro og udøvelsen af denne respekteret; muslimer har ret og pligt til at udbrede den islamiske lære, men ikke til at missionere og intendere omvendelse; muslimer har pligt til at forstå og omsætte koranens tekst til den virkelighed, man måtte leve i; muslimer har pligt til at engagere sig kon- 
struktivt i det samfund og den kultur, man er bosat i. Med disse principper in mente mener også Sherin Khankan at islamisk religiøsitet ikke bare kan eksistere konfliktløst, men også frugtbart med ethvert samfund og enhver tidsalder.

Både Tariq Ramadan og Sherin Khankan er sufister. Sufismen lægger vægten på det spirituelle aspekt i religionen, det er selve troen og ikke trosretningen, der er det essentielle. En sufist er ikke en god muslim, hvis han blot praktiserer de religiøse ritualer, mennesket skal tage det kald på sig at være muslim, og det indebærer at forstå, at kærligheden til Gud og forholdet til medmennesket er nøje forbundet. Troen er altså ikke en privat sag adskilt fra samfundet, men snarere en forudsætning for sameksistensen. Sufismen minder om sindelagsetik, som vi kender den fra Løgstrup, hvor ansvaret og omsorgen for næsten er centralt $\mathrm{i}$ troen. Khankan henviser da også til Løgstrup flere steder. I sufismens fokus på inderlighed og åndelighed genkender vesterlændingen også det personlige gudsforhold; vi har selv et ansvar for at begribe Guds vilje og vej. Dette individuelle aspekt er også grunden til, at sufisme af visse islamiske lærde er blevet set på som en trussel mod mere dogmatisk koranfortolkning. Den troende muslim må finde balancen mellem ydre praktisering og indre spiritualitet. Sharia er (ifølge sufismen) den fundamentale vejledning $i$ det at være praktiserende muslim, de fem søjler er en del af sharia. Så hvis muslimer skal afsværge sharia, svarer det til at ophøre med at være praktiserende muslim. Hvad man som muslim kan og bør gøre er at fordømme shariafortolkninger, som er barbariske og ude af trit med en moderne opfattelse af retfærdighed.

Sufismens anvendelse af tafsir og idtjihad skal også medvirke til, at den generelle ligestilling mellem mænd og kvinder $i$ islam skal følge den sekulære udvikling. Khankan reserverer et langt kapitel til at belyse kvindens stilling $\mathrm{i}$ islam, og det er tydeligt, at der er en del at tage fat på her. Der er en udbredt kønsadskillelse i den muslimske livsform og en favorisering af mænd, især når det gælder det at komme til orde i det offentlige rum. Moskeen er et af de rum, hvor der belyses og diskuteres religiøse, sociale og kulturelle emner. Det sker bl.a i khutbaen, som er talen inden fredagsbønnen. Det er Khankans ønske, at kvinder også skal kunne tage lederskabet i denne tale og fungere som imam.

Khankans personlige baggrund og hendes møde med sufismen førte til et mere formaliseret socialt engagement, idet hun i 2001 bliver medstifter af Forum for kritiske muslimer (FFKM). Foreningen arbejder for at udbrede debatten om islam og modernitet og for at give muslimer en platform, hvor de kan have deres religiøsitet med i et aktivt liv som samfundsborgere. Ifølge foreningens program har ingen monopol på en sand fortolkning af koranen. Men musli- 
mer har ret og pligt til at fortolke og efterleve koranens vejledning, således man ikke blot kan leve inden for det sekulære samfunds lovlige rammer, men også yde en aktiv indsats til gavn for det fælles samfund.

I redegørelsen for FFKM's virke genfindes mange aspekter fra omtalen af sufismen. FFKM er et forum for aktive muslimer med forskellige tolkninger af koranen, ikke nødvendigvis sufistiske. Men det er et krav, at medlemmerne kan tilslutte sig følgende manifest (s.98) i deres tilgang til koranen:

Fornuft: En rationel tilgang til fortolkning af koranen ved brug af idjtihad.

Fornyelse: Promovering af kvindeligt muslimsk lederskab.

Kritik: Selvkritik og kritik af reaktionære koranfortolkninger.

Mangfoldighed: En anerkendelse af divergerende fortolkninger af koranen og et opgør med sandhedsideologier.

Når man læser manifestet står det klart, at FFKM (eller er det Sherin Khankan?) må tage afstand fra Hizb ut-Tahrirs "omvendte orientalisme". Hizb ut-Tahrirs koranfortolkning vil i modsætning til FFKM konstruere en islamisk identitet, der definerer sig som modstander af Vesten og vestlige værdier, og som fornægter nødvendigheden af at anerkende mangfoldigheden og dynamikken i tafsir. Hizb ut-Tahrir lægger sig i sin monopolisering af sandheden i fjendeposition både i forhold til det seku- lære samfund og til store dele af det islamiske samfund.

Islam \& forsoning er en væsentlig bog, fordi den belyser en aktuel og nødvendig debat, som foregår i Europas muslimske kredse. Khankan har meget på hjertet, hun skriver $i$ en stil, der er sin egen blanding af religiøs patos, nøgternt informerende og personligt fortællende. Bogen fremstår ikke som en gennemkomponeret helhed, men mere som en samling artikler og indlæg $i$ standende debatter. Visse dele, for eksempel et afsnit om kvindelige konvertitter, virker nærmest som bilagsmateriale til en tørklædedebat, selvom Khankan søger at gøre dem til bevis på kvindens forbedrede ligestilling $\mathrm{i}$ islam. Også historien om Sherin Khankans forhold til De Radikale og til DR2's deadlineredaktion virker forstyrrende på bogens primære budskab.

For bogens ærinde er forståelse og forsoning - og det skal man aldrig afvise. Khankan præsenterer os for en moderne islam, som er ansvarlig og positiv i sin tilgang til at være samfundsborger. Men der er ingen tvivl om, at den kritiske muslim tager sin religion med i sine politiske og samfundsmæssige aktiviteter. FFKM har ikke på sin dagsorden at adskille religion og politik. Jeg tror ikke et moderne flerkulturelt Europa har anden mulighed end at lade sig bekræfte i forestillingen om, at vi selvfølgelig kan leve fredeligt og frugtbart sammen i sekulariserede samfund med hver vores tro - eller eventuelt helt 
uden tro. Karikaturkrisen har især gjort os i Nordeuropa ekstremt religionsforskrækkede. Religion associeres med fanatisme, terror, brud på menneskerettigheder; vi glemmer, at religion også kan være den grund som etiske og sociale holdninger formuleres ud fra.

Annette Moller

Kulturkanon - når Trine Dyrholm moder Soren Kierkegaard Kulturministeriet: Kulturkanon, Politikens Forlag, 2006, 256 sider, 99 kr.

På et godt besøgt pressemøde den 24. januar 2006 offentliggjorde Kulturministeriet den nye, danske kulturkanon. Den 15. august 2006 udkom Kulturkanon som bog med indlagt dvd og i et første oplag på anseelige 175.000 eksemplarer. Bogen præsenterer 96 udvalgte hovedværker inden for kunstarterne arkitektur, billedkunst, design \& kunsthåndværk, film, litteratur, populær- og partiturmusik og scenekunst.

Hos lederskribenter, hos anmeldere og hos hele den øvrige æstetiske gejstlighed har opfattelsen af denne nye kulturkanon aldrig været delt. Den har strakt sig fra det mildt medfølende til det maliciøse. Men aldrig positiv. Indvendingerne har været massive, og spørgsmålene har været massevis. Det mest relevante og mest repeterede spørgsmål har væ- ret, om man kan tillade sig at have en national, statsautoriseret kulturkanon. Er det så væsentligt at genrejse den nationale kultur, at en kulturkanon er nødvendig? Jørn Lund, formanden for kanonudvalgene, skriver i bogens introduktion, at "bogen her er ikke et pensum, den er uden løftede pædagogiske pegefingre, den er til inspiration for den enkelte $i$ arbejdet med at finde frem til den personlige kanon". Men kan det lade sig gøre? Kan staten udgive en kulturkanon uden løftede pegefingre? Kan staten udgive en kulturkanon blot som inspiration, så den enkelte kan udarbejde sin egen kanon? Kan staten i det hele taget udgive en aldeles indbydende, farveprægtig, rigt og smukt illustreret kulturkanon uden at forholde sig kritisk til, hvad det er for et begreb, de abonnerer på?

Kánon (ikke at forveksle med det etymologisk beslægtede kanón, hverken substantivet eller adjektivet) er lånt fra græsk, hvor det oprindelig har betydet 'rør, lige stok, rettesnor'. Det bruges (foruden om en bestemt slags flerstemmig sang) om tekstsamlinger, der er særligt udvalgte, og dermed har en særlig betydning som rettesnor. I Ordbog over det Danske Sprog defineres kanon som "regel; rettesnor; (mønstergyldig) forskrift; forbillede". Oprindelig var kanonbegrebet knyttet til religiøs litteratur. Begrebet, som vi anvender det, er hidkaldt fra den autoritære katolske kirke, hvor det er den samling af skrifter, der har været anerkendt som ægte siden oldkirken (i modsætning til de apokryfe skrifter, 